\title{
The environment and politics in science education: the case of teaching fracking
}

\author{
Lynda Dunlop $^{1}$ D . Lucy Atkinson ${ }^{1} \cdot$ Maria Turkenburg-van Diepen ${ }^{1}$
}

Received: 8 May 2020 / Accepted: 7 January 2021 / Published online: 11 February 2021

(c) The Author(s) 2021

\begin{abstract}
Hydraulic fracturing ('fracking'), like other complex social and environmental issues, is a controversy about science which raises educational questions about how best to prepare young people to understand, respond to and, where necessary, act (or not) in response. It raises political questions. We present a state-of-the-art review of research literature on fracking and education using systematic strategies, with a view to finding out how it is framed in educational situations and how politics enters the science classroom. This serves as an illustrative case of how contested scientific and technological interventions with implications for the environment and society are treated in school science. The review is supplemented by interviews with 10 teachers of science and engineering working in schools or colleges near sites of operational exploratory fracking. We find that the research literature on teaching hydraulic fracturing is sparse, with only 25 studies relating to teaching and learning about fracking. Few studies $(n=7)$ relate to high school education. Where it features in science education, fracking is used as a context for interdisciplinarity and critical thinking, and lends itself to approaches using discussion, dialogue and modelling. Outcomes from fracking education range include knowledge gains and critical thinking. Teachers interviewed tended not to see a place for fracking in the curriculum or in the classroom and were averse to including politics in upper high school science education. Our analysis suggests depoliticization through absence of this specific complex environmental issue from the public (education) sphere, reinforced by the desire for 'balance' in high school science education and instrumental approaches to science education which prioritize assessed learning outcomes. Dealing with complex social and environmental issues such as hydraulic fracturing in the years of compulsory science schooling is necessary because scientific knowledge is necessary but not sufficient to prepare young people for the critical scientific literacy required to meet sustainable development goals. There is a need to assess and respond to the educational needs of local communities affected by industrial interventions such as fracking. These findings are likely to be relatable to other issues where there are local and global consequences of action or inaction and where the environment and health are pitted against economic and energy demands.
\end{abstract}

Keywords Fracking $\cdot$ Teaching $\cdot$ Politics $\cdot$ Sustainable development $\cdot$ High school

Lead Editor: Anita Hussénius.

Lynda Dunlop

lynda.dunlop@york.ac.uk

1 University of York Science Education Group, Heslington, York YO10 5DD, UK 
In 2015, UN member states signed up to the 2030 Agenda for Sustainable Development (United Nations 2015), the core of which is 17 sustainable development goals (SDGs) including quality education (SDG 4), affordable and clean energy (SDG 7), clean water (SDG 6), decent work and economic growth (SDG 8) and climate action (SDG 13). Science education has a role to play in meeting the quality education goal and also in contributing to the other SDGs. In order to meet the SDGs, people need to know about technologies which have the potential to combat or contribute to the climate crisis and understand how to participate in public debate and to influence decision-makers, including those in politics and industry. Hydraulic fracturing (also referred to as 'fracking' and 'unconventional shale gas development') is an appropriate context for developing an understanding of the intersection between science and politics, particularly in communities where fracking is, or is proposed to be, operational.

Hydraulic fracturing is the extraction of shale gas and/or oil (fossil fuels) from underground reserves by drilling into rock and pumping, under high pressure, a mixture of water, sand and other chemicals into the rock to displace the fuel. 'Fracking' is a controversial term, with advocates of the process preferring 'unconventional shale gas development' or 'hydraulic fracturing'; in this article, we use 'fracking' as the abbreviation is the term commonly used in public discourse. Fracking is an example of a contemporary controversy about science. According to Milena Wazeck (2013), controversies about science are fundamental disagreements about the nature of a problem which relate to ethical, political, economic and social concerns and which are constrained by, although not resolved by, science. The actors in controversies about science include scientists, but also activists, politicians, industrialists and other stakeholders. Controversies about fracking arise due to differences in priorities relating to environmental justice, the need for a transition from fossil fuels to renewables to respond to the climate crisis, how best to achieve energy security and disagreements about the economic and social impacts. Chris Oulton, Justin Dillon and Marcus Grace (2004) suggest a number of principles for the teaching of controversial issues. These include focusing on the nature of the controversy, critical reflection on one's own views, promoting open-mindedness and curiosity to know more in order to inform decisions and motivating teachers to share their own positions, and the means by which they arrived at these, with students. Here, we focus on the specific case of the teaching of fracking to find out how controversial interventions with consequences for the environment and society are dealt with in school science.

Fracking is an example of a context in which scientific and technological knowledge comes into contact and conflict with economic, political, social and other forms of knowledge, and which requires critical scientific literacy in order to make well-justified decisions about the desirability of actions relating to fracking or anti-fracking. Education which focuses on preparing young people to understand and make decisions using science corresponds to scientific literacy as an aim of science education. According to Jesper Sjömström and Ingo Eilks (2015), scientific literacy is conceived in different ways, from a focus on scientific content and processes (Vision I), to a focus on contextualising science for application and meaning in life (Vision II), to a focus on politicization and global citizenship linked to sustainability and transformational learning (Vision III). All three visions imply the need to engage with socio-scientific issues, described by Troy Sadler (2009) as 'realworld, social issues with substantive associations to science' (p. 13), of which fracking 
is an example. As Aswathy Raveendran (2020) observes, many approaches to teaching socio-scientific issues focus on individual decision-making and run the risk of relativistic 'anything goes' conclusions over the need to work for the common good or broader societal well-being. Raveendran argues for greater attention to political literacy in science classrooms and for attention to the power relations that exist in society and to the role of science and technology in reinforcing inequalities. Our interest in fracking lies in the political dimensions of this socio-scientific controversy as an illustrative case of how energy, environment and science education intersect. Understanding how fracking is taught as a specific case can contribute to understanding of broader issues related to how other controversial scientific and technological issues are dealt with in science classrooms and thus identify the contribution of science education to meeting the SDGs.

In this study, we discuss the place of education about fracking in high school science and the inclusion of the political dimensions of science in high schools, before presenting the findings of the state-of-the-art review of fracking in education and interviews with teachers and discussing the implications beyond the context of fracking.

\section{Politics in school science education}

Fracking, like other environmental issues, necessarily involves politics because it is an activity that concerns people, the environment and decision-making about the two. Politics is defined by Colin Hay (2007, p. 77) as a social activity based on deliberation which occurs in situations of choice where there is potential for agency, and as such both fracking and fracking education are political issues. In this study, we draw on the approach to analysing political processes in science education used by Claes Malmberg and Anders Urbas (2019) in their study of stress. They identify a trend towards depoliticization of stress as presented in Swedish textbooks over recent decades such that stress is positioned as an individual issue, with its political dimensions rendered invisible, displacing it from the democratic agenda. Malmberg and Urbas (2019) draw on Hay's (2007) notion of politicization and depoliticization whereby depoliticization occurs when issues are demoted from the government sphere to the non-governmental (public and private) spheres, with the extent greatest when issues are relegated to the 'realm of necessity' and they are perceived to be non-changeable. Where an issue has been depoliticized to the extent that the activity is in the 'realm of necessity', i.e. considered unquestionable, it allows for power to be exerted unquestioningly. Depoliticization is also considered to happen when responsibility is transferred from national to trans-national level, from government to industry or consumers, or where human-designed processes or divine authority are invoked to deny deliberation, choice or human agency (Hay 2007). The focus on individual changes that individuals can make (in contrast to the social and political changes needed) in relation to environmental challenges such as the climate crisis suggests that depoliticization processes are also evident in relation to environmental issues. We were interested in exploring this by looking at the case of how hydraulic fracturing is taught.

One of the challenges associated with dealing with political issues in school science relates to how political issues are presented and perceived by teachers. Previous research by Ralph Levinson and Sheila Turner (2001) has found reports of lack of confidence and expertise amongst teachers to deal with sensitive issues, with perceptions that the role of a teacher is to 'teach the facts', with many believing that their teaching of science should be value-free; although as Mary Ratcliffe (2007) has observed, this is in itself a value 
statement. In previous work by one of the authors with Fernanda Veneu, it was found that teachers in England perceive balance to be both achievable and desirable in teaching controversies and that they see teaching about controversies as subordinate to teaching 'the facts', covering the curriculum and ensuring good examination outcomes (Dunlop and Veneu 2019). Teachers also identified concerns with what parents, the church and the school inspectorate would think, suggesting that a culture of surveillance, performativity and accountability is a challenge for teachers attempting to deal with controversial scientific issues with a political dimension.

The assumption of the desirability (leaving aside whether or not it is possible) has been questioned by Emily Eaton and Nick Day (2020) who describe the role of 'balance' in environmental education as a way in which education obstructs climate justice. Specifically, they note that balance legitimizes industry interests and perspectives. Alongside balance, Eaton and Day problematize the prioritization of industry perspectives and the focus on individual rather than social and political solutions to the climate crisis as 'petro-pedagogy' which acts against the possibility of students questioning or understanding the role of corporate power in the climate crisis.

Introducing the wider social and political contexts into science teaching has also been identified as a challenge for teachers by Chris Gayford (2002) on the grounds that teachers see their priority as maintaining the integrity of their subject through positive learning experiences rather than addressing or attempting to solve social, political and economic problems which are currently facing politicians and business leaders. This position, which prioritizes learning de-coupled from global challenges, can be linked to the current focus on holding teachers accountable for optimising student outcomes apparent in national and international educational policy. The focus on predetermined learning outcomes works against the preparation of students to deal with political dimensions of science. Matthew Clarke and Anne Phelan (2017) argue that instrumentalism (linked to the view that the main purpose of education is to serve the economy) and consensualism (the demonization of disagreement, particularly about the purpose of education) have acted together to depoliticize education. They argue that the result is the prioritization of improving teaching in order to improve student outcomes as the dominant discourse in education, with disagreement limited to the best ways to achieve optimal student outcomes. This logic squeezes out content and pedagogies which are not directly considered to improve student outcomes, no matter how important or relevant they are to the lives of children and young people.

\section{Fracking around the world}

Fracking takes place in many countries around the world including Argentina, Australia, Canada, Spain and the USA, but bans exist in some countries including close neighbours of England (Scotland, Ireland and France). At the time of writing this article, a moratorium on fracking in England had been announced because it is not currently possible to accurately predict the probability or magnitude of earthquakes linked to fracking operations' (Department for Business, Innovation and Skills 2019). Although widespread in the USA, the process has been opposed there and elsewhere for several reasons including but going beyond seismic activity, identified by Peter Jones, David Hillier and Daphne Comfort (2013): the use of water and potential release of hazardous chemicals into the environment, as well as the problems associated with development of non-renewables during the climate crisis. In the UK, the Environmental Audit Select Committee (House of Commons 
2015) identified concerns associated with fracking in relation to groundwater quality, waste, water supplies, air emissions and health, habitats and biodiversity, geological integrity and noise and disruption. In England (the context for this study), our previous work on young people's knowledge, beliefs and attitudes towards fracking in communities where it is located found negative and ambivalent attitudes towards fracking dominating, with opposition arising from concerns about water supply, pollution and other adverse environmental and economic impacts on the local community (Dunlop, Atkinson and Turkenburgvan Diepen 2020).

Although the controversy surrounding hydraulic fracturing raises educationally relevant questions, fracking does not appear in the English national curriculum (Department for Education 2015a, b) and a search of two large resource banks the-National STEM Learning resource library (STEM Learning 2020) and the TES resource library (TES 2020)returned few open-access resources for teaching fracking. In this study, we investigate how hydraulic fracturing is dealt with in educational contexts by conducting a state-of-the-art review as described by Maria Grant and Andrew Booth (2009), using systematic strategies to search current literature, synthesized with reference to the inclusion of the political dimensions of fracking in education. We supplement the research literature review with the analysis of ten interviews with teachers in a context where fracking has until recently (in November 2019) been active at an exploratory stage. We then discuss how the political dimensions of fracking are present or absent in fracking education in order to take stock of education about fracking and identify priorities for policy, research and practice.

\section{Research questions}

Fracking raises a number of educationally relevant questions about science and politics. As such education about fracking can contribute to the aims of science education for critical scientific literacy and sustainable development. Our intention was to learn how fracking is dealt with in the international research literature, with specific attention to how the political dimensions of fracking were treated. The overarching question that guides this review is 'What approaches are used in teaching and learning about fracking?' A second question is 'How are the political dimensions of fracking dealt with in fracking education?' To answer these questions, we use the methods outlined below.

\section{Methods}

This study analyses the research literature on education and hydraulic fracturing using the concepts of politicization and depoliticization in the tradition of Hay (2007) and Malmberg and Urbas (2019) in order to identify research trends and priorities in fracking education.

\section{The literature review}

A systematic search strategy was employed, drawing on methods developed by the Evidence, Policy and Practice Information (EPPI) Centre described by David Gough, James Thomas and Sandy Oliver (2012). Five social science and educational databases were searched: BEI (British Education Index), EPPI, ERIC (Education Resources Information Centre), Scopus and Web of Science. We searched only for articles written in English, 
published at any date until September 2019 (when the search was conducted). The search string used was: 'fracking' OR 'hydraulic fracturing' OR 'unconventional shale gas development' AND ‘young people' OR 'student* OR pupil*' AND 'school' OR 'university' OR 'college'. Taking an inclusive approach, we did not include the terms 'science', 'physics' or 'chemistry' in order to return studies relating to fracking in any educational context.

Of 143 papers returned, 126 were unique. All 126 papers were screened by two authors, using the abstract to determine whether or not the study met inclusion and exclusion criteria. Articles were included where they pertained to proposals or reports of teaching and learning about fracking and where there was data or reflection on the educational activity. Papers were excluded where they did not pertain to teaching or learning about fracking or did not include educationally relevant participants in their sample, for example, studies focusing on measurements of air pollution at fracking sites, or site-specific activist literature.

Initial screening of the abstracts reduced the sample to 41 by excluding studies not pertaining to education. In the group of 41 papers, three main categories of article remained: studies focused on the educational impacts of fracking, studies of attitudes towards fracking, and pedagogical proposals in relation to fracking. Further exclusion criteria were applied. Literature focusing on educational impacts of fracking (for example, comparisons between high school graduation rates in fracking and non-fracking communities) was excluded. Studies on public attitudes and perceptions were excluded unless they were reported alongside teaching and learning approaches. Finally, studies taking place on university campus but involving the wider public rather than students were excluded. Following screening, 25 papers remained in the study. These were read and a data extraction protocol completed by two authors. The data extracted included details including the country where the research was conducted, funding source, research questions, study aims, study design, methods, details of instruments, sample size, educational context and findings. Data extraction forms were analysed, with themes identified and refined through reflexive discussion. Papers were then grouped into categories according to the approaches to teaching and learning reported and analysed with reference to the concepts of politicization and depoliticization, with particular attention to how each paper dealt with the political dimensions of fracking.

\section{The interviews}

In-depth semi-structured interviews were conducted with 10 teachers of science and engineering in four schools and colleges within 20 miles of exploratory fracking sites in England. One taught engineering, one taught biology, three were teachers of chemistry and five taught physics. One teacher was female. Teachers were asked about their understanding of fracking, their experiences of teaching fracking and their perceptions of such teaching. Interviews lasted approximately $60 \mathrm{~min}$ and were audio-recorded.

Interviews were transcribed and analysed in vivo using a phased thematic approach as outlined by Virginia Clarke, Virginia Braun and Nicki Hayfield (2015) to identify patterns in the dataset. Following a data familiarization process, data were coded semantically, according to the interview questions and then according to research questions and finally using the concepts of politicization and depoliticization as defined by Hay (2007). We refer to politicization when fracking is the subject of deliberation and decision-making in a setting where previously it was not, and to depoliticization to the reverse and when there is a shifting of responsibility to individuals, or to rendering the political dimensions of the 
issue (in this case, fracking) invisible. All phases of data analysis were conducted by more than one author, with discussion associated with all coding decisions.

\section{Findings: the literature review}

Research literature on fracking education is sparse. The oldest dates from 2012. Few studies were published in highly ranked science education journals. Many of the articles were published in practitioner-focused publications, and although the proposals are interesting and/or novel, they often featured little systematic data collection or analysis. The majority of papers originate from the USA $(n=22)$. The geographical distribution reflects the fact that only papers written in the English language were included in the review and that the hydraulic fracturing industry is well-established in the USA where it has been operating for over a decade and perhaps also that fracking bans are active in some English speaking countries such as Ireland and Scotland. It was often not possible to know whether a study sample included participants located near fracking sites.

Studies did not always provide details of research questions, research design, methodology, student responses, sample sizes or methods of analysis, nor of the specific learning intentions associated with the activity reported. However, all articles included offered insights into classroom practice in relation to fracking.

Table 1 presents the distribution of studies by age range. The majority of studies report on fracking education at the university level. No papers focusing on primary education were returned.

The key themes identified in this group of papers were: that fracking is approached as an interdisciplinary context; approaches to teaching about fracking involve discussion and dialogue; modelling is used to teach about fracking and political processes; knowledge and critical thinking are common outcomes desired from teaching about fracking; and education can be used to inform community responses to fracking proposals. A range of teaching methods were reported, including model congress hearings, virtual internships, online research and use of videos. Where articles fall into more than one thematic category, they are discussed under the one that best corresponds to the focus of the paper.

\section{Fracking as a context for interdisciplinary learning}

Fracking was used as a context to apply knowledge and methods from different disciplines or where teaching involved students from more than one subject area. These tended not to be based in science classrooms. In the context of mathematics education, John Ross and Therese Shelton (2019) and Katie Hendrickson (2017) use fracking as a real-life social justice issue to teach statistical analysis and mathematical modelling, respectively. These articles position fracking as a social, economic and environmental concern. Whilst neither study included systematic collection or analysis of data, both contain teachers' reflections and some reported responses from students, suggesting that fracking is an appropriate context for teaching students about how mathematics can be used to understand or investigate real-world issues.

Fracking was featured as an interdisciplinary concern in environmental policy education contexts. These projects - a virtual internship set up by Sara Rinfret and Michelle Pautz (2015) and a simulated congressional hearing by Jeremy Stoddard and Jason Chen (2018) - took a substantial commitment of class time. The findings suggest positive 
Table 1 Studies by phase of education

\begin{tabular}{|c|c|c|}
\hline Education phase & Number of papers & Authors \\
\hline Middle and high school (age 11-19) & 7 & $\begin{array}{l}\text { Hendrickson (2017) } \\
\text { Lombardi et al. (2018a) } \\
\text { Lombardi et al. (2018b) } \\
\text { Monaco et al. (2016) } \\
\text { Solli et al. (2017) } \\
\text { Stoddard and Chen (2018) } \\
\text { Treick O'Neill (2012) }\end{array}$ \\
\hline School (unspecified) & 1 & Kennet and Engel (2018) \\
\hline Community college & 1 & Blue (2017) \\
\hline High school and university & 1 & Zowada et al. (2018) \\
\hline $\begin{array}{l}\text { University } \\
\text { In the following disciplines }\end{array}$ & 11 & See below \\
\hline Communication & 1 & Kahl (2018) \\
\hline Engineering & 3 & $\begin{array}{l}\text { Gannon et al. (2015) } \\
\text { Gannon et al. (2018) } \\
\text { Gannon et al. (2017) }\end{array}$ \\
\hline Environmental Science & 1 & Romine et al. (2017) \\
\hline Geology Mathematics (Statistics) & 1 & $\begin{array}{l}\text { d'Alessio et al. (2019) } \\
\text { Ross and Shelton (2019) }\end{array}$ \\
\hline Social Sciences & 1 & Poole and Hudgins (2014) \\
\hline Social sciences and science & 1 & Rinfret and Pautz (2015) \\
\hline STEM & 2 & $\begin{array}{l}\text { Burger et al. (2015) } \\
\text { Cutright (2015) }\end{array}$ \\
\hline Unspecified & 1 & Evensen (2017) \\
\hline Adult (unspecified) & 3 & $\begin{array}{l}\text { Cargas (2016) } \\
\text { Larri and Newland (2017) }\end{array}$ \\
\hline Unspecified & 1 & Liu (2012) \\
\hline Total & 25 & \\
\hline
\end{tabular}

outcomes for students, with reported gains in self-efficacy for political engagement, knowledge about fracking and understanding of fracking as a controversy, and gains in students' ability to identify an intended audience and political message from a video. Fracking was used in university communication teaching by David Kahl to help students analyse how power is communicated through language by industry and how industry obfuscates the cost to the environment associated with the profit motive.

In engineering education, students from different STEM (Science, Technology, Engineering, Mathematics) disciplines were assembled to address environmental topics. Teresa Cutright (2015) used interdisciplinary teams to solve problems associated with the remediation of flowback water from hydraulic fracturing. In this context, fracking was positioned primarily as an engineering and environmental issue rather than a political issue, with the focus on fracking as a context that can be used for the development of group work skills such as participation and leadership.

The group of studies on interdisciplinarity demonstrate the potential for fracking to be used to teach science as well as other STEM disciplines as well as politics and media literacy. There is a need for more robust research on the outcomes of teaching across disciplines in this way. All studies in this section except for Cutright (2015) reflect on fracking 
as a political issue and plan for ways in which students can learn about power and decision-making or use knowledge to inform their own decisions about fracking. Therefore, in the mathematics, policy and communication studies classrooms, fracking is positioned as a political issue. In the engineering education studies, hydraulic fracturing is presented as unquestionable, with only the details left to be resolved (e.g. how to deal with flowback water).

\section{Discussion and dialogue}

Discussion and dialogue were common approaches to fracking education, in both face-toface and online educational encounters. Discussion is taken to mean analysis and breaking down ideas through talk, where students address a question of common concern. Dialogue, according to David Bohm (1996), is a generative process of creating something new through differences in meaning identified in talk. Discussion was often used following a viewing of videos, typically showing contrasting perspectives on fracking, either online, as in a study of an online geology course by Matthew d'Alessio, Joshua Schwartz, Vicki Pedone, Jenni Pavia, Jenna Fleck and Loraine Lundquist (2019) or in class as in the university sustainability engineering context described by Paul Gannon, Ryan Anderson, Justin Spengler and Carolyn Plumb (2018). In the high school context, Julie Treick O'Neill (2012) discusses how the documentary Gasland (Fox 2011) was used to problematize the concept of 'trade-offs' with students. These studies describe positive outcomes from the approach, e.g. gains in perceived knowledge of fracking and engagement.

In the context of high school science, Anne Solli, Thomas Hillman and Åsa Mäkitalo (2017) make connections between interdisciplinarity and dialogic teaching in their investigation of students' controversy mapping about fracking during a three-week unit in natural sciences. Students engaged in a carefully structured research, discussion and communication project, and it was found that students handled multiple perspectives, referred to and evaluated sources, distanced themselves from the message and provided evidence. These activities, related to dialogue and argumentation, mirror competences required to participate in public discussion about fracking and to become scientifically literate.

The studies featuring discussion and dialogue suggest that fracking is an appropriate topic because it is controversial: people can legitimately hold different positions on fracking, and these may change as new evidence or ideas are presented. There are indications that these processes can bring about learning, but learning intentions are often unclear (particularly for non-science learning) or narrowly focused on science or engineering. This points to the need for more systematic research on the impact of these strategies, including on students' understanding of social and political processes.

\section{Modelling science and politics}

A model is defined by Janice Gobert and Barbara Buckley (2000, p. 891) as a 'simplified representation of a system which concentrates attention on specific aspects of the system'. Models were used in multiple ways: to represent political processes (Rinfret and Pautz 2015; Stoddard and Chen 2018), mathematical processes (Hendrickson 2017), scientific processes (Peter Kennett and Natascha Engel 2018) and scientific explanations (Lombardi et al. 2018a, b).

The model of fracking liquid (Kennett and Engel 2018) focuses on the nature of materials used in fracking liquid, using household items to model the composition of the liquid. 
It suggests that students draw conclusions from the liquid 'input' that may not apply to the liquid output. Whilst the model might enable students to relate to some of the chemicals used in the process, it does not involve them handling chemicals that cause neurodevelopmental or neurological effects. According to Ellen Webb, Julie Moon, Larysa Dyrszka, Brian Rodriguez, Caroline Cox, Heather Patisaul, Sheila Bushkin and Eric London (2018) such chemicals are widely used in and produced by fracking process. This model is also limited in that it does not raise awareness of the problems of storage, transport and treatment of waste products or draw attention to the water demands of the process. This misses the opportunity to teach about the environmental (including land use) and political dimensions of fracking. As with the use of models more generally, it is important to consider the strengths and limitations of the model with students.

Mathematical models were developed by students in response to their own questions (of an economic, political, environmental and scientific nature) about fracking such as how much fracking fluid would be lost underground in the USA if it was not controlled? and what percentage of the US uses fracking methods? (Hendrickson 2017), demonstrating how fracking can help students use mathematics come to a view on fracking.

Political models (Rinfret and Pautz 2015; Stoddard and Chen 2018) enabled students to learn about fracking through simulated political processes (stakeholder groups, drafting policy papers, preparing for a congressional hearing). Students reported gains in learning about environmental policy making and fracking, as well as enjoyment of the process. Whilst a more robust treatment of learning gains (in different disciplinary dimensions) is needed, political models appear to be engaging for students and the existing evidence suggests that they bring about learning across disciplines.

The studies using political and mathematical models show potential for teaching about fracking using a range of disciplinary approaches, but the challenge is the duration of activities, with most taking place over a day or over several weeks. This would be challenging for many teachers, with their concern for curriculum coverage, particularly at age 14-16, and the difficulty that Victoria Wong and Justin Dillon (2019) report teachers experiencing in working across disciplines associated with the asymmetric dependence of science on mathematics. However, the reports suggest that these practices can make a contribution to placing fracking and fracking education into the public sphere where teachers can find the time to incorporate them into teaching.

The following categories relate to desired outcomes for teaching about fracking.

\section{Critical thinking}

Fracking was used as a context to develop or assess critical thinking skills in students. We use Robert Ennis' (2011) definition of critical thinking as 'reasonable reflective thinking focused on deciding what to believe or do'. Fracking was used as a context for teaching critical thinking through controversies by Sarita Cargas (2016), and by Dennis Liu (2012) for raising awareness of how a range of denialist tactics-including conspiracy theories, fake experts, cherry-picking of data, impossible expectations of research and the misrepresentation of opposition viewpoints-are used to undermine science. Whilst the identification, elaboration and discussion of such tactics are useful to educators, there is scope for further work on how these can be applied to fracking and included in science teaching and research into their effectiveness. STEM-based problem solving was used in a multidisciplinary context by Paula Monaco, Aimee Cloutier, Guo Zheng Yew, Maeghan Brundrett, Dylan Christenson and Audra Morse (2016), who worked with female high school students 
in a summer school to design a fracking site, constrained by site conditions, but those of a political nature were not discussed.

In high school science, Lombardi et al. (2018a, b) propose the use of Model-EvidenceLink activities (MEL) to help students to evaluate the plausibility of different explanations for seismic activity near fracking sites, finding that instructional scaffolds in the form of evidence statements and scientific and alternative model explanations helped students learn earth science content and to evaluate the validity of explanations based on evidence, albeit only to a modest extent. The focus here was on seismic activity, the impacts of which are better established than some of the other environmental impacts of fracking, but arguably less of a concern to young people living in fracking communities than water and air pollution and the social impacts identified by our previous empirical work on the knowledge, beliefs and attitudes of youth (Dunlop, Atkinson and Turkenburg-van Diepen 2020). The MEL approach by Lombardi et al. (2018a, b) could be expanded to make students aware of the limits and limitations of scientific evidence and to make better connections with regulatory and industrial practices.

Using a two-tier multiple choice instrument to assess critical thinking, QuASSR (Quantitative Assessment of Socio-Scientific Reasoning), William Romine, Troy Sadler and Andrew Kinslow (2017) found that only 2\% of variation in socio-scientific reasoning is explained by knowledge about fracking, suggesting that teaching more content is not the most productive way to improve socio-scientific reasoning. They suggest that identifying complexity and recognising that problems are difficult to resolve are some of the easier tasks associated with socio-scientific reasoning. More challenging tasks were understanding that decisions are confounded by the interests of stakeholders, even when rigorous scientific data are available, and that there is often a need for additional data. This suggests a learning progression for introducing socio-scientific reasoning about fracking in science classes. The set of studies on critical thinking tended to make use of the wider social, political, environmental and economic considerations, except where this was taking place in an engineering context, where fracking is treated in the 'realm of necessity', generating only technical questions.

\section{Knowledge}

Pedagogical proposals for teaching or assessing fracking focused on knowledge. These included short teaching interventions such as presentations and role play used in Germany and the USA by Christian Zowada, Ozcan Gulacar and Ingo Eilks (2018), short lectures in the case of Joanna Burger, Kimi Nakata, Laura Liang, Taryn Pittfield and Christian Jeitner (2015) and more extended courses such as that reported by Darrick Evensen (2017). Where testing of knowledge pre- and post-intervention was used, studies reported knowledge gain for students, but this tended not to relate to the environmental, social or health impacts of fracking. Evensen (2017) tested the link between knowledge and attitudes, finding over the course of a 13-week intensive course that a change in self-evaluated knowledge about fracking and its impacts was reported but with little change in students' attitudes.

Whilst knowledge gain is an appropriate learning outcome, it is important to define what knowledge relates to and consider the extent to which fracking can be separated from its social, environmental and economic impacts, not to mention the best ways to identify knowledge gain and retention in relation to complex issues. Alternative approaches to assessing knowledge about complex issues include mind mapping as used by Nikita Burrows and Suazette Reid Mooring (2015) and the creation of actor networks as used by 
Renee-Marie Fountain (1999). Whilst these might be difficult to apply in large scale survey settings, the findings might be more illuminating-particularly if used in classroom settings - than those gained through surveys that reduce knowledge to a perception or a small number of multiple choice items.

\section{Community education}

The final group of papers reporting pedagogical proposals were rooted in educational responses to fracking in local communities. These deal mainly with adult education in specific contexts affected by fracking or the prospect of fracking. For example, Amanda Poole and Anastasia Hudgins (2014) located an ethnographic field school for teaching research methods in a fracking community, and Stacie Blue (2017) reported a model of a college working with their wider community to bring knowledge about fracking to inform decision-making. These studies demonstrate how education embedded in communities can help develop understanding of the issues associated with fracking (in the former paper) and how this can be used within community decision-making processes (in the latter). These studies deal with political and environmental aspects of fracking.

Education supporting resistance to fracking operations was observed in Larraine Larri and Maxine Newlands' (2017) analysis of the production of gender in two anti-fracking documentaries used in education about coal seam gas (held in coal seams rather than shale, but also extracted by hydraulic fracturing). This study problematizes the use of documentaries in education, arguing whilst Frackman (Nasht, Lake and Todd 2015) has educational benefits in relation to informing people about the shale gas industry, it reiterates gender blindness, barely including the stories of females as activists, in contrast with Knitting Nannas (O'Keeffe (Producer) and Brown (Director) 2014), which presents learning as an inclusive community of practice through which people deepen their knowledge and understanding through interactions with each other.

The studies on fracking education in the community place social and political considerations as central, and whilst they do not reference science education, science educators have an important role to play in supporting people in these communities to understand and interpret scientific evidence and use it to promote sustainability through transformational learning, in line with Vision III scientific literacy (Sjömström and Eilks 2015).

\section{Findings: interviews with teachers}

Interviews with teachers revealed little appetite for teaching fracking in upper high school science and even less for including the broader political dimensions of the issue. They felt that it was not appropriate to address this in upper high school science classes due to the nature of the subject, the curriculum, the students, and the place of politics and the environment in school science. Whilst local interests were seen to be important, they were overridden by national interests such as curriculum and examinations.

\section{The nature of the subject in the upper high school}

Although teachers saw fracking as an important issue, particularly for their local population, they saw no place for fracking in post-compulsory science education (i.e. post-16). In terms of the subject, teachers linked fracking to energy supplies (physics), hydrocarbons 
(chemistry) and climate change (biology) but believed that whilst it might be mentioned, there was not enough science associated with fracking for it to feature in upper high school science, reporting that 'I think with fracking there isn't enough physics in it' and 'once you've named it, I'm not that clear in my own mind where you'd go with it'. The teachers suggested alternative places for fracking education, for example in religious studies or personal, social, health and citizenship education, but recognized that these subjects also featured heavy curricula, where fracking would be competing with, for example, sexual health and preventing violent extremism.

Would it be a better idea to talk about these things in a more generalized setting? So, looking at it from their point of view, whether it's a more business economic point of view, whether it's more environmental point of view, and you get people discussing the same issue but from different angles. And I think that that's that could be quite important because then you get a more balanced view rather than 'this is the science behind it'.

Science during the compulsory stage (11-16) was also considered an appropriate place for teaching about fracking, although none of the teachers in the study had taught about it at that level. Pushing out fracking — and environmental and political issues more broadlyfrom science education, particularly at a post-compulsory stage sends a message that science can be divorced from the political context and that such concerns are not the concerns of scientists.

\section{The nature of the curriculum in upper high school science}

Unsurprisingly, teachers were guided by curriculum and assessment requirements. Where fracking did not appear on their curriculum (A level physics, chemistry and biology, the main qualifications for post-16 science in England), they did not plan to include it in their lessons. Further, it was seen to be unrelated to material that was on the curriculum, reporting that 'In terms of their daily lives they ask about it, but in terms of what they need to know for an examination, certainly for chemistry, there'd probably be nothing in there'. This response was common amongst all science teachers interviewed: 'there's nothing that relates directly to fracking that we would teach about...there's no real opportunity to talk about fracking'. Some hypothesized that the absence of fracking was due to its relatively recent appearance (in England) as a technique for extracting gas. This suggests a disconnect between the curriculum and education to meet the sustainable development goals which prioritizes (for example) climate action and clean energy or a lack of resources that connect fracking and curriculum content.

Although the curriculum prescribes the minimum content required, teachers felt under pressure to teach what was there and saw little scope for going beyond the curriculum, constrained by what they saw as a content-heavy curriculum and high stakes assessment. Some curricula did include possibilities to teach about fracking, but these qualifications were sometimes perceived to be under-valued by universities, who were seen to drive decisions about what science students need to be successful in higher education: 'A few years ago, we had the old General Studies A level where you could discuss and debate those kinds of things. But of course, now we don't because universities don't recognize it'.

The absence of fracking was considered to be related to the type of content in the curriculum: 
There isn't so much in A level or in GCSE [General Certificate of Secondary Education, a qualification taken at age 16] of what they used to call how science works. This whole sort of global picture of, you know, the idea of how we use science and society and how science affects society and all that sort of stuff.

Teachers felt that fracking would need to be included in the curriculum in such a way that it gives them 'license' to teach: although they saw fracking education as 'important' they felt it could only be given attention in class if valued by awarding bodies and universities. This prioritisation of national rather than local interests represents depoliticization. Power is seen to rest not with teachers, but with a distant abstraction (the curriculum). The decision to include or exclude issues such as fracking based on the content of the current curriculum is both limited in the sense of restricting the teaching and learning of science to centrally dictated content statements from the qualification awarding body, and limiting, in that it obstructs access to contexts for application of scientific knowledge and skills which can be used to better understand and influence decisions taken in the world. There is a need to think creatively about curriculum connections between the environment and science, for example drawing on Hendrickson's (2017) example applying mathematical concepts and processes to answering students' questions about fracking.

\section{The nature of upper high school science students}

Some of the teachers saw the nature of activity that might be required to teach about fracking to contrast with the interests and skills of the students who selected sciences, particularly physics. Teachers were pessimistic about how open students would be to discussion and debate, observing that:

Students who have a certain characteristic in nature, are out of their comfort zone because they're like, 'well, I need to know that equation' or 'I need to know that calculation'. It's like 'why do I have to talk about something that's so there is no answer to? I want to know an answer. I have to get to an answer'. And so that open debate ... we do get the occasional student that has that ability. But in science, you find it's more of a sort of closed sort of mindset.

This suggests the need to discuss with students how research scientists operate at the frontiers of knowledge, where there is no known answer. With no requirement to use specific approaches, teachers reported avoiding experiences that would be uncomfortable for students. However, it is important for students to have supportive experiences outside their comfort zones in order to learn. The instrumental attitudes of some students were also perceived to be a barrier to addressing fracking, for example 'We have those kids just naturally intrigued and want to know... and the others are like, well, is this on my examination? Then I don't want to know'. Even in instrumental terms, it is important to challenge these attitudes from students because an education limited by what is assessed is unlikely to prepare young people well for life beyond the classroom where knowing how to use scientific knowledge to inform opinions and decisions, as well as how to deal with disagreement and difference, and learning how to hold power to account are needed in the private as well as the public (e.g. further education and employment) spheres. Instrumentalism reinforces regimes of obstruction to environmental justice in education by squeezing out what is not prescribed.

Science students were also considered to have less of a need for education about fracking as they were thought to possess critical thinking skills necessary for interpreting 
information about the issue: 'I don't see why it needs to be the specialist scientists would study it because they've probably got critical faculties to do some independent research'. This undermines the role of education in developing critical thinking and argumentation skills. It also relies on the motivation and curiosity of individual students to find out for themselves. Teachers were open to-and did - have conversations with their students about fracking. Indeed, this is how teachers in the study taught fracking, i.e. in response to student interest in an environmental extracurricular activity, in conversation or in support of a student's work for the extended project qualification (EPQ, an extended and open-ended investigation into a topic conducted independently by a student).

You're always going to get students that mention things that are in the news and again, as teachers, we might talk about local issues and what's in the news, terms of science. So, it has come up because it's been so, so prevalent...[it] is more what you might just talk about the five minutes of beginning of a lesson.

These less formal conversations offered scope for addressing topics not on the curriculum and in response to students' interests. However, the push towards personal rather than public conversations about fracking depoliticizes the issue, and the reliance on student interest risks marginalising this and other important environmental and political issues in high school science.

\section{The place of politics in upper high school science}

Teachers noted the importance of fracking as a local issue and contrasted this with its absence from science education, noting that it 'is almost noticeable as an omission'. Fracking was seen by teachers as a political issue, and they perceived that politics did not belong in science classrooms, reporting that 'you have to be careful not to be political in the classroom....as a scientist, you want to always present both sides to any retaining science or consensus'. There was little recognition that all education is inherently political and that presenting 'both sides' is a political position in itself. There was no space to deal with complex situation where no consensus exists or to help students learn how to deal with dissensus. There is opportunity to see these situations as opportunities for learning about how science and government works, and about the strengths, limits and limitations of science, rather than barriers to teaching science.

Teachers described how, when dealing with topics, their focus is first on teaching their subject and that it is unlikely that they would consider broader political, economic and environmental considerations: 'I think the difficulty is, if you're looking at it from say a chemistry point of view, the focus will be on the chemistry that's involved with the process, and it wouldn't be about the bigger picture'. This focuses on technical competence (Vision I scientific literacy) rather than science for application and meaning in life (Vision II) or for sustainability and transformation (Vision III) and contrasts with how scientific research is being funded in response global challenges (UK Research and Innovation 2020) and the international focus on responsible research and innovation (European Commission 2020).

Not only was it undesirable for teachers to deal with politics in science classes, but teachers in the study felt that most teachers had not been trained well to deal with managing classroom discussion, and that they would find it uncomfortable to do so: 'I think it would be a long way outside of most physics teachers' comfort zones to be discussing those kinds of influences because it's from anything else that we deliver'. This suggests a 
need for attention to pedagogical approaches for dealing with politics in school science in pre- and in-service teacher education.

\section{The place of the environment in science education}

Teachers linked the absence of fracking in the curriculum to the absence of environmental issues more broadly. Teachers saw the place for fracking in relation to climate change, energy and renewables, but noted that 'I think [the environment]'s a footnote in the year 12 work'. The environment was seen as secondary to subject specific ideas:

But it's in terms of the environmental impact is there, but it's more tip your hat to it isn't it? You know, do you understand the chemistry?...it's not really the environmental impact, you know... syllabuses are written to the chemistry.

For example, one teacher observed that:

It seems to me that not just A level but at GCSE, that there's actually less attention paid to the whole renewables argument versus fossil fuels than there was even when I started teaching....in ' 86 .

This contrasted with what teachers saw as the purpose of science education, which included making students more aware of local issues, understanding science in their own lives, and developing scientific literacy, noting that 'this is an example of something where...you can show students how these things are ongoing or important to make informed decisions' and 'to encourage the students to become scientifically literate, as they're participating in those democratic decisions, and they'll come relatively shortly to them. I think on that basis, it wouldn't be right to avoid the issue'. This demonstrates that teachers see a conflict between the current curriculum and an education for scientific literacy that allows students to find out about science and how it impacts their own lives. Whilst teachers saw fracking as important, they felt it was more appropriate for students to learn about it elsewhere.

\section{Discussion}

Whilst we focus here on fracking, it is important to consider this in the context of wider environmental issues, and indeed other political issues in science, particularly those which affect populations in different and inequitable ways. Our first research question asked 'what approaches are used in teaching and learning about fracking?' In a systematic search of research literature, we found presentations, films, discussion, critical thinking scaffolds, models, virtual internships and problem-solving scenarios used to teach about fracking in different disciplinary contexts. However, the research literature in relation to teaching and learning about fracking is sparse, particularly at high school level, in science lessons, and outside the USA. In the UK (the context for this study), few open-access teaching resources are available on popular databases, and teachers tend not to see a place for teaching fracking in upper high school science. Similarly, Zowada et al. (2018) found that fewer than half of their student research participants saw a place for fracking in the curriculum or reported that fracking motivated them to learn chemistry in depth, suggesting that there is little appetite for fracking education. This contrasts with youth demands for climate education (UK Student Climate Network 2020). Teachers in communities affected by fracking tended not to teach about it in science lessons, citing incongruence with the subject, curriculum 
and students. They were, however, open to encounters with fracking in non-formal spaces, e.g. in conversation or in after-school activities, but did not see a place for the political dimension of the issue. There is a need to bring these local environmental issues into the classroom if one of the aims of education is to prepare young people for life and decisionmaking. Education about fracking can contribute to climate education by raising awareness of the greenhouse gas contributions of fracking, drawing attention to the social and environmental impacts of the process and problematising the focus on extreme extraction technologies rather than renewables.

Our second research question was 'how are the political dimensions of fracking dealt with in fracking education?' Our literature review found that the political dimensions are largely absent from the engineering education literature, but that elsewhere the political dimensions are dealt with by providing modelled or simulated experiences, providing opportunities for students to conduct research online to inform their views, teaching media literacy, for example to recognize how industry communicates its message and about how denialist tactics can be used to undermine science.

Hydraulic fracturing is absent from an important dimension of the public sphere (education) at the time at which there is greatest need for citizens to be informed and able to participate in political processes relating to what hydraulic fracturing means for their community, their country and the planet. If students in England are to encounter fracking during their compulsory education, it relies on the interests and capacities of themselves and their teachers and is likely to occur as incidental conversations which do not enter the political realm. Encounters, however, are improbable given the prevailing culture in schooling, whereby assessment drives what happens in the classroom, and teachers are disincentivized from opening up discussion about political issues, fearing responses from parents and senior leaders when dealing with controversy, particularly where it is not a curriculum requirement. Hay (2007) suggests that the absence of discussion points towards efforts to depoliticize the issue. We suggest that this is the case here: the absence of fracking from education documents and resources in the UK acts to silence discussion on the issue and remove it from the public sphere. If politics is defined as a social activity based on deliberation that happens in situations of choice where there is capacity for agency (Hay 2007), fracking is not presented as such in UK science education.

Malmberg and Urbas (2019) discussed the extent to which teaching resources presented possibilities for social change in the context of stress. In this study, we were interested in whether or not the processes of depoliticization evident in relation to health education would also be prevalent in relation to the environment. Here we find fracking largely invisible in research literature, the curriculum and teaching, and where it does appear the political dimensions of the issue are absent. In the international research literature, social and political responses to fracking were featured, but they tended to make large demands on time, and were often in higher education contexts where multiperspective approaches tended to be found in non-majors courses, suggesting that issues such as fracking which require an understanding of multiple perspectives are squeezed out of the compulsory curriculum. Malmberg and Urbas (2019) attribute invisibility to depoliticization, where the issue is positioned outside the democratic space. In the present study, we found science teachers opposed to dealing with the political dimensions of fracking in science lessons, and the desire to teach for 'balance' was evident in their responses, whether by presenting all stakeholder interests as equally weighted, or by ensuring that students are presented with viewpoints from, e.g. industry and the environmental movement. Eaton and Day (2020), reporting on the Canadian context, argue that this emphasis on balance has been a deliberate strategy promoted by the fossil fuel 
industry to defend itself from action against climate change. The aspiration for balance, focus on individual decisions and preferences, and the rejection of politics from science education takes politics out of education. With these depoliticization processes within teaching contexts, instrumental approaches to education which prioritize academic attainment in relation to predetermined learning outcomes obstruct education relating to non-curriculum content. Possible consequences include the public being poorly informed about the economic, environmental, scientific and social impacts of fracking, and about the political processes through which decisions are made and therefore less able to hold policy makers to account. There is a need to question the desirability and possibility of balance when teaching about issues relating to the environment and sustainability. If science education is to contribute to the scientific literacy needed to meet the UN sustainable development goals, there is a need to identify and challenge the regimes of obstruction to climate justice associated with petro-pedagogy.

More transformational approaches were found in communications and community education, where there were reports of engaging with fracking communities, at times informing decision-making in response to opportunities to lease land for fracking. Science education has the potential to make a strong contribution to meeting the sustainable development goals, but to do so, there needs to be greater use of critical pedagogies which identify and challenge assumptions and priorities which reinforce existing inequalities. Research literature offering and reporting on pedagogical proposals was political to different extents. Engineering education tended to present fracking as a nonpolitical fact-of-life, with only questions of efficiency and improvement up for discussion. This may be at least in part attributable to the fact that fracking was at times used as a context for focusing on core disciplinary knowledge or other skills, e.g. critical thinking or group work. However, the absence of politics renders fracking in engineering education a depoliticized issue, where it is not questioned. Absence has the potential to fuel apathy or according to Matt Wood and Matthew Flinders (2014, p. 159) 'deny the existence of choice in relation to certain issues' which in turn facilitates depoliticization at the governmental level. According to Hay (2007), depoliticization is problematic because it insulates politicians from their choices and protects them from responsibility and critique, and it results in the belief amongst the wider population that the status quo cannot be changed.

At the other end of the spectrum, some of the proposals that drew on models, simulations and discussion and dialogue incorporated the political-and other-dimensions of fracking. In these scenarios, students were allowed to find out about fracking before participating in discussion relating to the model. This enabled them to understand the science of fracking and also how decisions can be made and influenced. Whilst these approaches took time, they were able to support students to learn about fracking as a controversy, as well as how political processes work. Fracking is therefore positioned as a political issue, but the space for public participation through education tended to be squeezed into the non-compulsory educational space.

Interviews with teachers in schools near fracking sites in England revealed contradictions between what they saw as the purpose of education-in terms of scientific literacy, preparing young people to participate in decision-making processes and demonstrating how knowledge creation in science continues in the context of fracking - and what the subject, curriculum and students demand. They felt no licence to address fracking, despite seeing it as an important local issue, with many of their students affected by the process. Teachers saw no place for politics in school science and believed balance to be essential. This was in common with approaches found in the research literature, for example the presentation of 
documentaries from industry representatives alongside those of environmentalists and the absence of discussion about whether or not all positions should be given an equal weight.

Fracking is a contemporary controversy about science that can be understood with general high school science: it brings together chemistry (understanding fracking liquid), physics (energy production), and earth science (how gas is stored in shale). Fracking, like other contemporary and controversial issues associated with the environment in science education, is associated with questions of power and decision-making. It is important not to neglect the political controversy about fracking because it can provide insight into how science works, how scientific questions, methods, claims and evidence can be interpreted, and how new scientific and social scientific questions can be generated, as well as how science is constrained and co-opted by dominant power structures. This could be considered an example of what Eaton and Day (2020) describe as 'petro-pedagogy' which acts against the possibility of students questioning or understanding the role of corporate power in the climate crisis.

The limitations of the study relate to our narrow focus on fracking. There are likely to be useful approaches to the teaching of fracking to be found in the literature on socio-scientific issues; however, our interest was specifically on how fracking is dealt with rather than how it might be dealt with. The literature search was limited to articles written in English, and we are likely to have missed important studies in other languages. Similarly, the majority of the studies identified were produced in the USA, representing a narrow geographical region. The interviews with teachers were also limited, focusing on teachers in areas where fracking was operational. This is unlikely to be representative of teaching elsewhere, but the study was conducted at a time when fracking was high on the UK government and public agenda, and we were interested to find the disconnect between the world (where fracking made the national news) and the classroom (where there were few resources to support teaching about fracking and teachers saw no place for fracking education).

\section{Conclusions}

This study has found a reluctance to deal with fracking as a political issue in science education and persistence of the view that science education is not political. Whilst we do not advocate politics in terms of telling students what to think, we advocate telling students what to think about. The current situation appears to reflect the obstruction of environmental justice in science classrooms through the mechanisms of absence and avoidance and an insistence on balance as both achievable and desirable. This suggests a need for a work with beginning and in-service teachers to problematize the curriculum, its content and its assessment, asking whose needs it serves, which values it prioritizes, and which interests are missing, and to collectively find ways to 'go beyond' prescribed content to respond to social (including local) needs. Approaches which are likely to be useful here include placebased pedagogies which address the social and ecological places where people actually live as described by David Gruenewald (2003) and environmental case studies modelled on Paul Gorski and Seema Pothini's (2013) case studies on diversity and social justice in education. Also, Larry Bencze, Chantal Pouliot, Erminia Pedretti, Laurence Simonneaux, Jean Simonneaux and Dana Zeidler (2020) offer an holistic, critical approach to science education which takes account of the social and political systems through the use of Socially Acute Questions (SAQ), Socioscientific Issues (SSI) and Science, Technology, Society and Environment (STSE) education which extend contextual approaches to science education. 
Our own position is that young people need to understand how science interacts with politics, and about how decisions about science and technology are made. For students who plan to become scientists or engineers, they need to be are aware of the social and political implications of their work. For all students, there is a need to identify where science and technology can help people live more sustainability, where science and technology is used to promote unsustainable and inequitable practices, and to enable young people to understand and contribute to local, national and super-national political processes where the decisions made have an impact on well-being and quality of life. In the context of fracking, there is a need to include this in school science, at least in those areas affected, where fracking is presented as a solution to global and national energy and economic needs and as long as the climate crisis demands a just transition to renewables. More broadly, there is a need for education to respond to local needs and go beyond instrumental approaches where the curriculum is seen as the totality of education, rather than the minimum. Education must confront scientific and technological interventions that impact on local communities so that people in those communities are able to hold industry and government to account through participation in political processes. Participation might include both formal (through government consultation processes, for example) and non-formal (for example protest and other forms of activism) processes. Scientific knowledge is necessary but not sufficient to prepare young people for the critical scientific literacy required to meet sustainable development goals: understanding how science interacts with power is a necessary component of Vision III scientific literacy for transformation linked to democracy. Dealing with both the political and scientific dimensions of hydraulic fracturing in the years of compulsory science schooling is necessary as long as fracking is presented as a solution to global and national energy needs.

Acknowledgements We would like to thank the teachers who participated in this study, and Estelia Bórquez-Sánchez for her Spanish summary of the study. Funding was provided by University of York (Education Department Small Grant).

Open Access This article is licensed under a Creative Commons Attribution 4.0 International License, which permits use, sharing, adaptation, distribution and reproduction in any medium or format, as long as you give appropriate credit to the original author(s) and the source, provide a link to the Creative Commons licence, and indicate if changes were made. The images or other third party material in this article are included in the article's Creative Commons licence, unless indicated otherwise in a credit line to the material. If material is not included in the article's Creative Commons licence and your intended use is not permitted by statutory regulation or exceeds the permitted use, you will need to obtain permission directly from the copyright holder. To view a copy of this licence, visit http://creativecommons.org/licenses/by/4.0/.

\section{References}

Bencze, L., Pouliot, C., Pedretti, E., Simonneaux, L., Simonneaux, J., \& Zeidler, D. (2020). SAQ, SSI and STSE education: Defending and extending "science-in-context". Cultural Studies of Science Education. https://doi.org/10.1007/s11422-019-09962-7.

Clarke, V., Braun, V., \& Hayfield, N. (2015). Thematic analysis. Qualitative psychology: A practical guide to research methods, pp. 222-248.

Bohm, D. (1996). On dialogue. Abingdon: Routledge.

Burrows, N. L., \& Mooring, S. R. (2015). Using concept mapping to uncover students' knowledge structures of chemical bonding concepts. Chemistry Education Research and Practice, 16(1), 53-66. https://doi. org/10.1039/C4RP00180J.

Clarke, M., \& Phelan, A. (2017). Teacher education and the political: The power of negative thinking. Routledge. 
Department for Business, Energy and Industrial Strategy. (2019). Guidance on fracking: developing shale gas in the UK. Retrieved from: https://www.gov.uk/government/publications/about-shale-gas-andhydraulic-fracturing-fracking/developing-shale-oil-and-gas-in-the-uk. Accessed 6 July 2020.

Department for Business, Energy and Industrial Strategy. (2019). Government ends support for fracking. Retrieved from: https://www.gov.uk/government/news/government-ends-support-for-fracking. Accessed 6 July 2020.

Department for Business, Innovation and Skills. (2019). Government ends support for fracking. [online] Available at: https://www.gov.uk/government/news/government-ends-support-for-fracking.

Department for Education. (2015a). National curriculum in England: Science programmes of study. Retrieved from: https://www.gov.uk/government/publications/national-curriculum-in-england-scienceprogrammes-of-study/national-curriculum-in-england-science-programmes-of-study. Accessed 6 July 2020 .

Department for Education. (2015b). Combined science GCSE subject content. Retrieved from: https://asset s.publishing.service.gov.uk/government/uploads/system/uploads/attachment_data/file/800339/Combi ned_science_GCSE_updated_May_2019.pdf. Accessed 6 July 2020.

Dunlop, L., Atkinson, L., \& Turkenburg-van Diepen, M. (2020). Perspectives on fracking from the sacrifice zone: Young people's knowledge, beliefs and attitudes. Chemistry Education Research and Practice, 21(3), 714-729. https://doi.org/10.1039/D0RP00022A.

Dunlop, L., \& Veneu, F. (2019). Controversies in Science. Science \& Education, 28(6-7), 689-710. https:// doi.org/10.1007/s11191-019-00048-y.

Eaton, E. M., \& Day, N. A. (2020). Petro-pedagogy: Fossil fuel interests and the obstruction of climate justice in public education. Environmental Education Research, 26(4), 457-473. https://doi. org/10.1080/13504622.2019.1650164.

European Commission. (2020). Responsible research and innovation. Retrieved from: https://ec.europa.eu/ programmes/horizon2020/en/h2020-section/responsible-research-innovation.

Ennis, R. (2011). Critical thinking. Inquiry: Critical thinking across the disciplines, 26(2), 5-19. https://doi. org/10.5840/inquiryctnews201126215.

Fox, J. (2011). Gasland. [Motion Picture]. International Wow Company prod.: Gasland prod.

Fountain, R. M. (1999). Socio-scientific issues via actor network theory. Journal of Curriculum Studies, 31(3), 339-358. https://doi.org/10.1080/002202799183160.

Gayford, C. (2002). Controversial environmental issues: A case study for the professional development of science teachers. International Journal of Science Education, 24(11), 1191-1200. https://doi. org/10.1080/09500690210134866.

Gobert, J. D., \& Buckley, B. C. (2000). Introduction to model-based teaching and learning in science education. International Journal of Science Education, 22(9), 891-894. https://doi.org/10.1080/0950069004 16839.

Gorski, P. C., \& Pothini, S. G. (2013). Case studies on diversity and social justice education. Abingdon: Routledge.

Gough, D., Thomas, J., \& Oliver, S. (2012). Clarifying differences between review designs and methods. Systematic Reviews, 1(1), 28. https://doi.org/10.1186/2046-4053-1-28.

Grant, M. J., \& Booth, A. (2009). A typology of reviews: an analysis of 14 review types and associated methodologies. Health Information \& Libraries Journal, 26(2), 91-108. https://doi.org/10.111 1/j.1471-1842.2009.00848.x.

Gruenewald, D. A. (2003). The best of both worlds: A critical pedagogy of place. Educational Researcher, 32(4), 3-12. https://doi.org/10.3102/0013189X032004003.

Hay, C. (2007). Why we hate politics. Polity.

House of Commons. (2015) Environmental risks of fracking-environmental audit. Retrieved from https:// publications.parliament.uk/pa/cm201415/cmselect/cmenvaud/856/85606.htm. Accessed 6 July 2020.

Jones, P., Hillier, D., \& Comfort, D. (2013). Fracking and public relations: Rehearsing the arguments and making the case. Journal of Public Affairs, 13(4), 384-390. https://doi.org/10.1002/pa.1490.

Levinson, R. (2001). Valuable lessons: Engaging with the social context of science in schools: Recommendations and summary of research findings. London: The Wellcome Trust.

Malmberg, C., \& Urbas, A. (2019). Health in school: Stress, individual responsibility and democratic politics. Cultural Studies of Science Education, 14(4), 863-878. https://doi.org/10.1007/s1142 2-018-9882-0.

Nasht, S., Lake, T., Todd, R. (Producer), Todd, R., \& Stack, J. (Director). (2015). Frackman [Motion picture]. Australia: eOne, Madman.

O’Keeffe (Producer), S., \& Brown (Director), R. (2014). Knitting Nannas [Motion picture]. Australia: Frogmouth Films. 
Oulton, C., Dillon, J., \& Grace, M. M. (2004). Reconceptualizing the teaching of controversial issues. International Journal of science education, 26(4), 411-423. https://doi.org/10.1080/095006903200007 2746.

Ratcliffe, M. (2007). Values in the science classroom-the 'enacted' curriculum. In D. Corrigan, J. Dillon \& R. Gunstone (Eds.), The re-emergence of values in science education. Rotterdam: Sense Publishers. Ch. 9 .

Raveendran, A. (2020). Invoking the political in socioscientific issues: A study of Indian students' discussions on commercial surrogacy. Science Education. https://doi.org/10.1002/sce.21601.

Sadler, T. D. (2009). Situated learning in science education: Socio-scientific issues as contexts for practice. Studies in Science Education, 45(1), 1-42. https://doi.org/10.1080/03057260802681839.

Sjöström, J., Rauch, F., \& Eilks, I. (2015). Chemistry education for sustainability. In I. Eilks \& A. Hofstein (Eds.), Relevant chemistry education - from theory to practice (pp. 163-184). Rotterdam: Sense.

STEM Learning. (2020). Resources www.stem.org.uk/resources. Accessed 6 July 2020.

United Kingdom Research and Innovation. (2020). Themes and programmes. Retrieved from: https://www. ukri.org/research/themes-and-programmes/.

United Nations. (2015). Transforming our world: The 2030 agenda for sustainable development. Retrieved from: https://sustainabledevelopment.un.org/content/documents/21252030\%20Agenda\%20for\%20Sus tainable\%20Development\%20web.pdf. Accessed 6 July 2020.

UK Student Climate Network. (2020). We, the students demand... Retrieved from: https://ukscn.org/ourdemands/ Accessed 25 October 2020.

Wazeck, M. (2013). Marginalization processes in science: The controversy about the theory of relativity in the 1920s. Social Studies of Science, 43(2), 163-190. https://doi.org/10.1177/0306312712469855.

Webb, E., Moon, J., Dyrszka, L., Rodriguez, B., Cox, C., Patisaul, H., et al. (2018). Neurodevelopmental and neurological effects of chemicals associated with unconventional oil and natural gas operations and their potential effects on infants and children. Reviews on Environmental Health, 33(1), 3-29. https ://doi.org/10.1515/reveh-2017-0008.

Wong, V., \& Dillon, J. (2019). 'Voodoo maths', asymmetric dependency and maths blame: why collaboration between school science and mathematics teachers is so rare. International Journal of Science Education, 41(6), 782-802. https://doi.org/10.1080/09500693.2019.1579945.

Wood, M., \& Flinders, M. (2014). Rethinking depoliticization: Beyond the governmental. Policy \& Politics, 42(2), 151-170. https://doi.org/10.1332/030557312X655909.

\section{Papers from systematic search included in the review}

Blue, S. (2017). Protecting the sacred water bundle: Educating about fracking at Turtle Mountain Community College. Tribal College Journal of American Indian Higher Education. Retrieved from http:// tribalcollegejournal.org/protecting-the-sacred-water-bundle-educating-about-fracking-at-turtle-mount ain-community-college/. Accessed 6 July 2020.

Burger, J., Nakata, K., Liang, L., Pittfield, T., \& Jeitner, C. (2015). Effect of providing information on students' knowledge and concerns about hydraulic fracking. Journal of Toxicology and Environmental Health-Part A: Current Issues, 78(9), 595-601. https://doi.org/10.1080/15287394.2015.1017683.

Cargas, S. (2016). Honoring controversy: Using real-world problems to teach critical thinking in honors courses. Honors in Practice, 12, 123-137. https://files.eric.ed.gov/fulltext/EJ1104362.pdf.

Cutright, T. (2015). Use of an undergraduate, interdisciplinary design team to address the remediation of fracking water and acid mine drainage. 26.1640.1-26.1640.13. https://doi.org/10.18260/p.24977.

D’Alessio, M. A., Schwartz, J. J., Pedone, V., Pavia, J., Fleck, J., \& Lundquist, L. (2019). Geology goes hollywood: Building a community of inquiry in a fully online introductory geology lecture and laboratory. Journal of Geoscience Education. https://doi.org/10.1080/10899995.2019.1578467.

Evensen, D. (2017). If they only knew what I know': Attitude change from education about 'fracking'. Environmental Practice, 19(2), 68-79. https://doi.org/10.1080/14660466.2017.1309884.

Gannon, P., Anderson, R., \& Plumb, C. (2017). Research initiation: Effectively integrating sustainability within an engineering program research initiation: Effectively integrating sustainability within an engineering program: Executive summary.

Gannon, P., Anderson, R., Spengler, J., \& Plumb, C. (2015). Exploring contemporary issues in sustainable energy. 26.725.1-26.725.9. https://doi.org/10.18260/p.24062.

Gannon, P., Plumb, C., \& Hacker, D. (2018). Frack attack: An engaging classroom activity to integrate sustainability (Vol. 52, pp. 226-231). 
Hendrickson, K. (2017). Fracking: Drilling into math and social justice. Mathematics Teaching in Middle School.

Kahl, D. H., Jr. (2018). Critical communication pedagogy as a response to the petroleum industry's neoliberal communicative practices. Communication Teacher, 32(3), 148-153. https://doi.org/10.1080/17404 622.2017 .1372600 .

Kennett, P., \& Engel, N. (2018). The fracking debate. Teaching Earth Sciences, 43(1), 31-33.

Larri, L. J., \& Newlands, M. (2017). Knitting Nannas and Frackman: A gender analysis of Australian anticoal seam gas documentaries (CSG) and implications for environmental adult education. Journal of Environmental Education, 48(1), 35-45. https://doi.org/10.1080/00958964.2016.1249325.

Liu, D. W. C. (2012). Science denial and the science classroom. CBE Life Sciences Education, 11(2), 129134. https://doi.org/10.1187/cbe.12-03-0029.

Lombardi, D., Bailey, J. M., Bickel, E. S., \& Burrell, S. (2018a). Scaffolding scientific thinking: Students' evaluations and judgments during Earth science knowledge construction. Contemporary Educational Psychology, 54(June), 184-198. https://doi.org/10.1016/j.cedpsych.2018.06.008.

Lombardi, D., Bickel, E. S., Bailey, J. M., \& Burrell, S. (2018b). High school students' evaluations, plausibility (re) appraisals, and knowledge about topics in Earth science. Science Education, 102(1), 153177. https://doi.org/10.1002/sce.21315.

Monaco, P., Cloutier, A., Yew, G. Z., Brundrett, M., Christenson, D., \& Morse, A. (2016). Assessment of K-12 outreach group project highlighting multidisciplinary approaches in the oil and energy industry. https://doi.org/10.18260/p.26332.

Poole, A., \& Hudgins, A. (2014). "I care more about this place, because I fought for it": Exploring the political ecology of fracking in an ethnographic field school. Journal of Environmental Studies and Sciences, 4(1), 37-46. https://doi.org/10.1007/s13412-013-0148-6.

Rinfret, S. R., \& Pautz, M. C. (2015). Understanding Public Policy Making through the Work of Committees: Utilizing a student-led congressional hearing simulation. Journal of Political Science Education, 11(4), 442-454. https://doi.org/10.1080/15512169.2015.1060886.

Romine, W. L., Sadler, T. D., \& Kinslow, A. T. (2017). Assessment of scientific literacy: Development and validation of the Quantitative Assessment of Socio-Scientific Reasoning (QuASSR). Journal of Research in Science Teaching, 54(2), 274-295. https://doi.org/10.1002/tea.21368.

Ross, J., \& Shelton, T. (2019). Supermarkets, highways, and natural gas production: Statistics and social justice. Primus, 29(3-4), 328-344. https://doi.org/10.1080/10511970.2018.1456497.

Solli, A., Hillman, T., \& Mäkitalo, А. (2017). Navigating the complexity of socio-scientific controversieshow students make multiple voices present in discourse. Research in Science Education. https://doi. org/10.1007/s11165-017-9668-5.

Stoddard, J., \& Chen, J. (2018). Exploring the impact of virtual internships for democratic and media education introduction, pp. 1695-1696.

TES. (2020). Lesson resources. https://www.tes.com/teaching-resources. (2019).

Treick O'neill, J. (2012). Fracking: In the end, we're all downstream. Retrieved from Rethinking Schools website: https://www.rethinkingschools.org/articles/fracking-in-the-end-were-all-downstream. Accessed 6 July 2020.

Zowada, C., Gulacar, O., \& Eilks, I. (2018). Incorporating a web-based hydraulic fracturing module in general chemistry as a socio-scientific issue that engages students. Journal of Chemical Education, 95(4), 553-559. https://doi.org/10.1021/acs.jchemed.7b00613.

Publisher's Note Springer Nature remains neutral with regard to jurisdictional claims in published maps and institutional affiliations.

Lynda Dunlop is a member of the University of York Science Education Group. Her research focuses on the inclusion of philosophical and political approaches in high school science, and on educational practices aligned with authentic science.

Lucy Atkinson is a member of the University of York Science Education Group. Her research focuses on the political dimensions of education.

Maria Turkenburg-van Diepen is a member of the University of York Science Education Group. Her research focuses on scientific literacy, raising school students' awareness of opportunities for careers and their role as scientifically literate citizens. 